\title{
Smart Mirror Technology on Internet of Things to Enhance Interacive Learning
}

\author{
Mochammad Haldi Widianto ${ }^{1}$, Ranny ${ }^{2}$, Nathasia Florentina Thejowahyono ${ }^{3}$, Seto Benson Handoyo ${ }^{4}$ \\ 1,2,3,4 Informatics Departement, School of Computer Science, Bina Nusantara University, Jakarta, Indonesia, \\ 11480 \\ *Corresponding Author: ${ }^{1}$ mochamad.widianto@binus.ac.id \\ ${ }^{2}$ ranny@binus.ac.id
}

\begin{abstract}
At present, the development of the Internet of Things (IoT) technology that is continuing very rapidly. Various household appliances directly have the nickname "SMART", other things with mirror technology, technology is one of the most common things in life, especially in the field of education, still in a relatively primitive state. The possibility of using mirrors is still not in demand, so innovation in saying IoT has not been felt. Several studies involving microcontrollers can already be applied using mirrors, so the term "Smart Mirror" appears, where the use of microcontrollers has entered innovation through mirrors. Smart Mirror is based on traditional mirrors in households that have scheduling automation systems, turning on video, music etc. Students need technology for smarter lives. Smart Mirror provides students with a range of intelligent experiences such as device control, information acquisition, environmental monitoring, entertainment. Based on the development of a microcontroller, unidirectional mirror, frame and other hardware devices, a smart mirror, as a mirror display screen, offers a more convenient, faster, faster and smarter, information-based type. In the research succeeded in making some smart mirror innovations needed for students and can be used for daily living, especially in the university area in Bandung.
\end{abstract}

Key words : Smart Mirror, Internet of Thing, Digital Learning.

\section{INTRODUCTION}

Today, the rapid progress in the world of devices, leading to almost every corner of the human being on this earth, everyone and everything can do close and long-distance communication. Now, this technology provides information and communication between anyone, anywhere, or at any time. What is now called the Internet of Things (IoT)[1],[2]-[4].
IoT is called the future Internet version that will allow machine-to-machine (M2M) learning. The permanent idea behind the IoT curtain is to have independent communication, secure power and enable the exchange of real information for everyone on earth, for both software and hardware applications. IoT activates connections between real-life physical causes and the virtual world [5].

The means of Internet interaction have moved forward very quickly connecting zillions or other things both good and bad information throughout the world, and some such things from various processing capabilities, sizes, computations and forces with the help of several helper applications. Therefore, there is an idea to combine traditional technology on the Internet with future Internet technology that is very smart, IoT allows tangible objects to connect and communicate as well as to equip them with intelligence to process information specifically. This information can then be used to make socially and technologically useful decisions [6]. The general IoT scenario is illustrated in the figure. 1

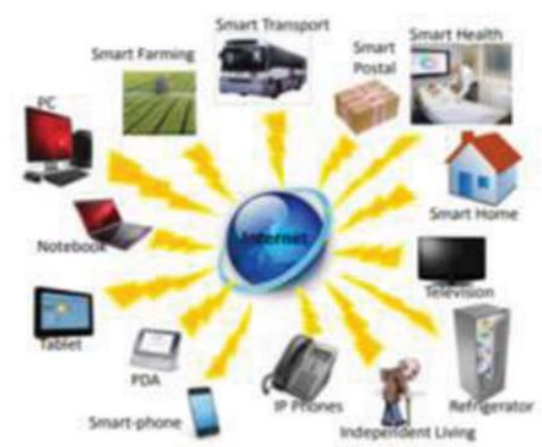

Figure 1: The generic IoT scenario [7]

This is supported by using innovative technology to achieve interactive and effective education. A screen that has reflective properties such as a mirror makes students and students more curious when the learning process occurs. Based on the development of a microcontroller, unidirectional mirror, frame and other hardware devices, a smart mirror, as a mirror display screen, offers a safer, more convenient, faster, more precise and smarter type, information-based to support quality education. So hopefully, 
this tool will help students be more creative, innovative and more interested in all subjects [8]-[10].

In previous studies, several studies that rarely explored the use of smart mirrors in the world of education, most of them were used for the benefit of industry, offices and households. So the author tries to do some experiments on the use of smart mirrors in the world of education, especially directly conducting experiments in several courses that the author is capable of.

For research in the field of education itself, only a few researchers using improvised tools have not used much copyright technology to increase student involvement. Even to increase student and lecturer innovation, there are not many tools that can support this kind of interaction [11][12][13].

This research was made to be applied at Bina Nusantara University in Bandung with dynamic features so that some online features can be displayed on the mirror layer. Mirrors can also be used as active learning using unique glass markers and lanterns that turn on automatically. The fundamental difference with an ordinary mirror is; mirrors on smart mirrors can interact such as telling to-do-lists to help information about the course and also added other features such as videos to help on large tasks in the course such as; Game Programming. Then, it is also hoped that smart mirrors can collaborate with game maker software, where the game maker software is very interactive and open.

\section{RELATED WORK}

In the Previously research [9], a kind of smart mirror can be used for people's daily activities, designed in this paper is the use of a smart mirror that can be used in lectures. Subsequent research [5], used a smart mirror for home security because of its reflective nature so that not many people were allowed into the house. More clearly will be elaborated through the following table:

Table 1: Previous research

\begin{tabular}{|l|l|l|l|}
\hline NO & $\begin{array}{l}\text { Autho } \\
\mathrm{r}\end{array}$ & Title & Result \\
\hline 1 & {$[9]$} & $\begin{array}{l}\text { IoT by Cisco } \\
2011\end{array}$ & $\begin{array}{l}\text { Use of IoT as capital to } \\
\text { enter Smart Mirror } \\
\text { technology }\end{array}$ \\
\hline 2 & {$[14]$} & $\begin{array}{l}\text { Smart mirror: A } \\
\text { time-saving and } \\
\text { affordable } \\
\text { assistant }\end{array}$ & $\begin{array}{l}\text { Smart Mirror is used as } \\
\text { a household support, } \\
\text { where every family can } \\
\text { do all activities and } \\
\text { household needs }\end{array}$ \\
\hline 3 & {$[15]$} & $\begin{array}{l}\text { Smart Mirror } \\
\text { using Raspberry } \\
\text { Pi as a Security } \\
\text { and Vigilance } \\
\text { System }\end{array}$ & $\begin{array}{l}\text { Smart Mirror is used } \\
\text { for home security to } \\
\text { avoid crime in urban } \\
\text { areas }\end{array}$ \\
\hline
\end{tabular}

\begin{tabular}{|c|c|c|c|}
\hline 4 & [16] & $\begin{array}{l}\text { Voice } \\
\text { Controlled } \\
\text { Smart Mirror } \\
\text { with Multifactor } \\
\text { Authentication }\end{array}$ & $\begin{array}{l}\text { This research } \\
\text { explain how simple } \\
\text { microcontroller devices } \\
\text { can be used to make } \\
\text { smart mirror with very } \\
\text { high intelligence and } \\
\text { security }\end{array}$ \\
\hline 5 & [17] & $\begin{array}{l}\text { Smart } \\
\text { Interactive } \\
\text { Mirror Display }\end{array}$ & $\begin{array}{l}\text { the mirror monitors its } \\
\text { own } \\
\text { temperature and } \\
\text { humidity levels so that } \\
\text { if the bathroom } \\
\text { becomes } \\
\text { potentially harmful to } \\
\text { the computer's } \\
\text { hardware }\end{array}$ \\
\hline 6 & {$[18]$} & $\begin{array}{l}\text { Smart Mirror for } \\
\text { Home and Work } \\
\text { Environment }\end{array}$ & $\begin{array}{l}\text { Here the idea of Smart } \\
\text { Mirror originated, } \\
\text { Modern } \\
\text { equipment requires } \\
\text { input through hardware } \\
\text { and renders } \\
\text { an interface that } \\
\text { requires little effort to } \\
\text { access information } \\
\text { This mirror allows } \\
\text { users to access data } \\
\text { easily and quickly }\end{array}$ \\
\hline 7 & [19] & $\begin{array}{l}\text { Development of } \\
\text { A Smart Mirror } \\
\text { with Life Log } \\
\text { Functions and } \\
\text { Its Evaluation }\end{array}$ & $\begin{array}{l}\text { the system has a Kinect } \\
\text { v } 2 \text { RGBD camera and } \\
\text { a } 4 \text { K LCD display built } \\
\text { behind } \\
\text { half-transparent mirror } \\
\text { to } \\
\text { extract the user motion }\end{array}$ \\
\hline 8 & [20] & $\begin{array}{l}\text { Internet of } \\
\text { Things Security - } \\
\text { Multilayered } \\
\text { Method } \\
\text { For End to End } \\
\text { Data } \\
\text { Communication } \\
\text { s Over Cellular } \\
\text { Networks }\end{array}$ & $\begin{array}{l}\text { Internet of Things } \\
\text { device to a host } \\
\text { through a cellular } \\
\text { network }\end{array}$ \\
\hline 9 & [21] & $\begin{array}{l}\text { Internet of } \\
\text { Things and } \\
\text { Crowd Sourcing } \\
\text { - a Paradigm } \\
\text { Change for the } \\
\text { Research on the } \\
\text { Internet of } \\
\text { Things }\end{array}$ & $\begin{array}{l}\text { It gives an overview of } \\
\text { the IoT Lab } \\
\text { architecture for IoT and } \\
\text { crowdsourcing } \\
\text { integration, including } \\
\text { the use of IPv6 as a } \\
\text { global integration } \\
\text { enabler }\end{array}$ \\
\hline
\end{tabular}

The tools created in this paper function as smart devices so as to improve teacher performance through this technology. Device design adopts a microcontroller as a processing control centre in fulfilling all signal processing. Smart Mirror 
has so many modules.

Which include external imaging controls, wake touch, voice conversion, image capture and face recognition processing, voice recognition and other interactive programs, to realise the functions of display information, voice interaction, human perception, intelligent security, entertainment etc.

\section{DESIGN HARDWARE AND SOFTWARE}

The overall framework and working principles in this study are in accordance with the following picture:

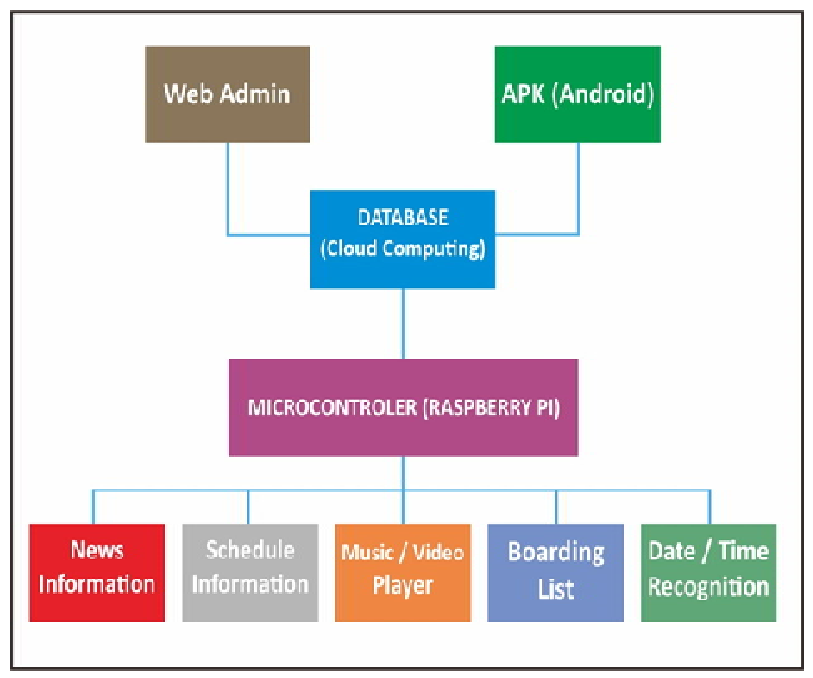

Figure 2: Smart Mirror Flow Diagram Function

The system is structured to give users full access to all services and functions through the database server as the core of the database; then the database can be accessed and controlled using WebAdmin. The database is also integrated by the microcontroller, with the tools provided such as; access to information, scheduling, music and video players, job list boards and finally time and date recognition. It is expected that in the future all the tools provided can interact with software such as Unity as assistance from various courses such as Game Engine Development so that they can interact for the purposes of several courses.

The next figure depicts a schematic picture of the system, which can be divided into three different parts:

- Physical structure

- Smart mirror software

- Cloud

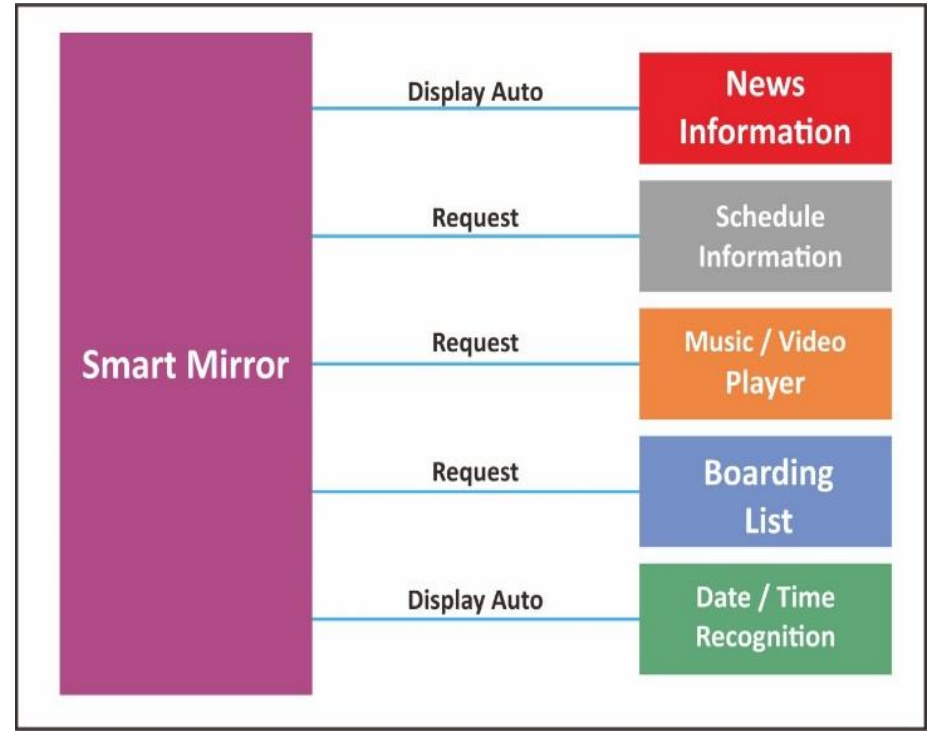

Figure 3: System Drawing

\section{DESIGN IMPLEMENTATION}

After setting up a number of tools and making this technology, researchers conducted several schemes to meet the objectives

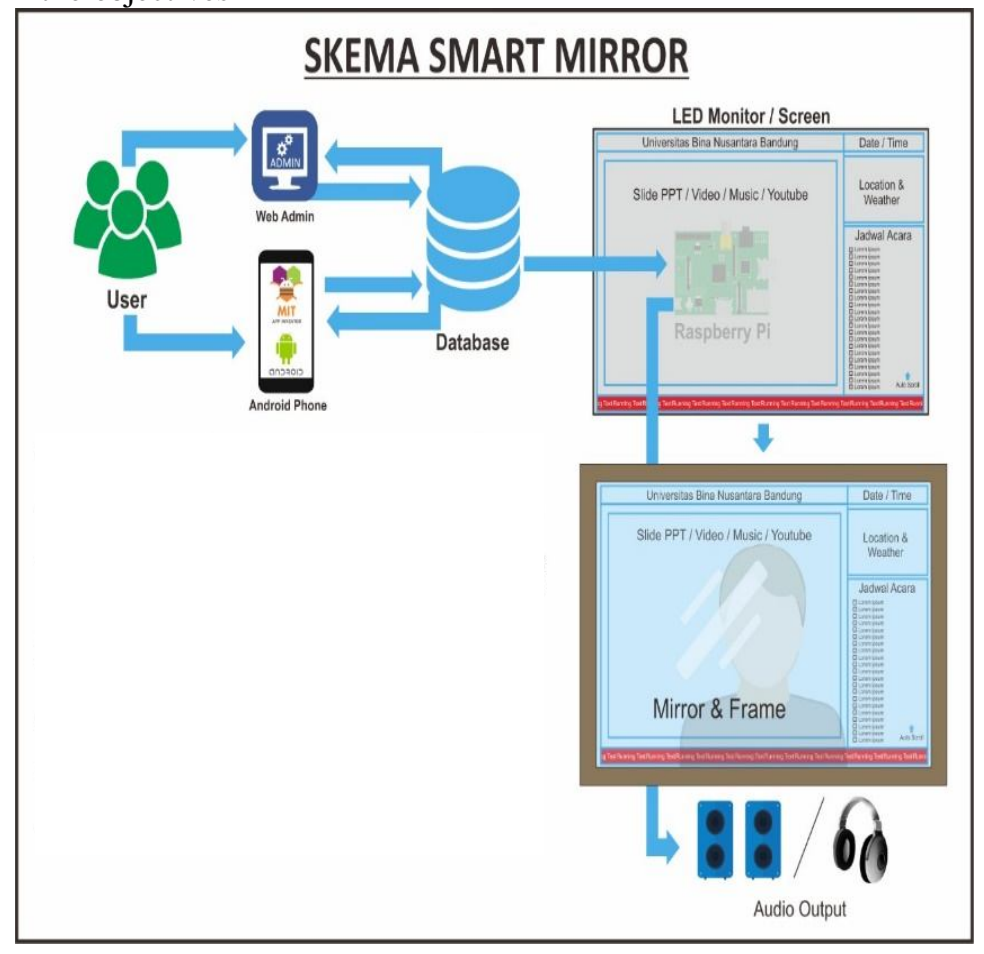

Figure 4: Smart Mirror Scheme

The control system of a smart mirror consists mainly of one-way mirrors, driver boards, screens, and so on. The control system is the basic system of mirror display and human-computer interaction [22]. In accordance with the nature of the mirror, so that it can display daily information 
such as accessing the Internet and databases, including weather, news, time and so on. Smart Mirror can connect the user's mobile phone through a WLAN network using Web-Based, change the contents of the word board, monitor the mirror image, etc. Explain how it works in Figure 5.

Where the scheme as in Figure 5 explains if the image above uses a landscape display that functions to see the information to be displayed and has a form of video, slides, ppt and pdf. Then it is optimal in the form of landscape, because of the scale of the resolution comparison. The Figure 5 scheme also explains the alternating direction from the database to the web, and the database to (android and app inventor) means that the system on the smart mirror can be changed and various innovation applications. It is created by students, teachers and lecturer. This will facilitate several courses that require innovative objects as a medium of learning.

\subsection{Login Menu}

Here the website can be accessed because it has been done hosting and domain with the domain name http://cms-binus.iprasetya.site/. Following Figure 6 is the Login view that will be the initial display when accessing the web admin.

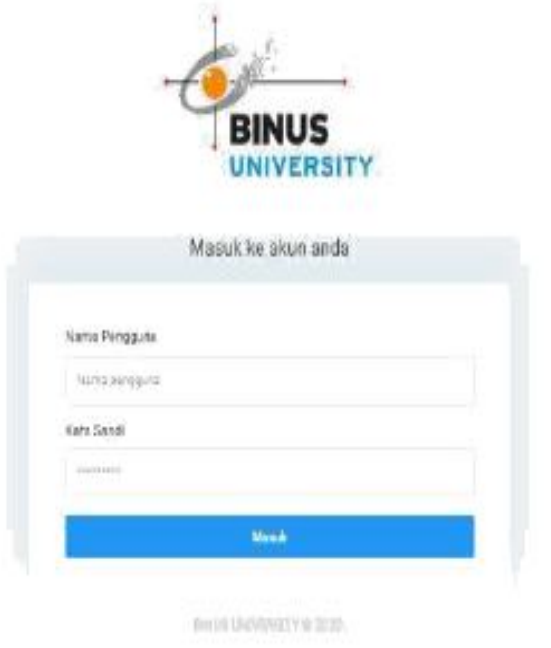

Figure 5: Display login page

Based on Figure 5 is the initial display image when accessing the web admin. The login page is the initial gateway to be able to access the web admin from Smart Mirror, which functions to enter data that will be stored in a database and then it will be displayed on the Raspberry Pi.

\subsection{Dashboard Menu}

Based on Figure 6 is a dashboard display image after logging in. Dashboard page serves to provide information about the number of media, the number of events and the amount of advertising.

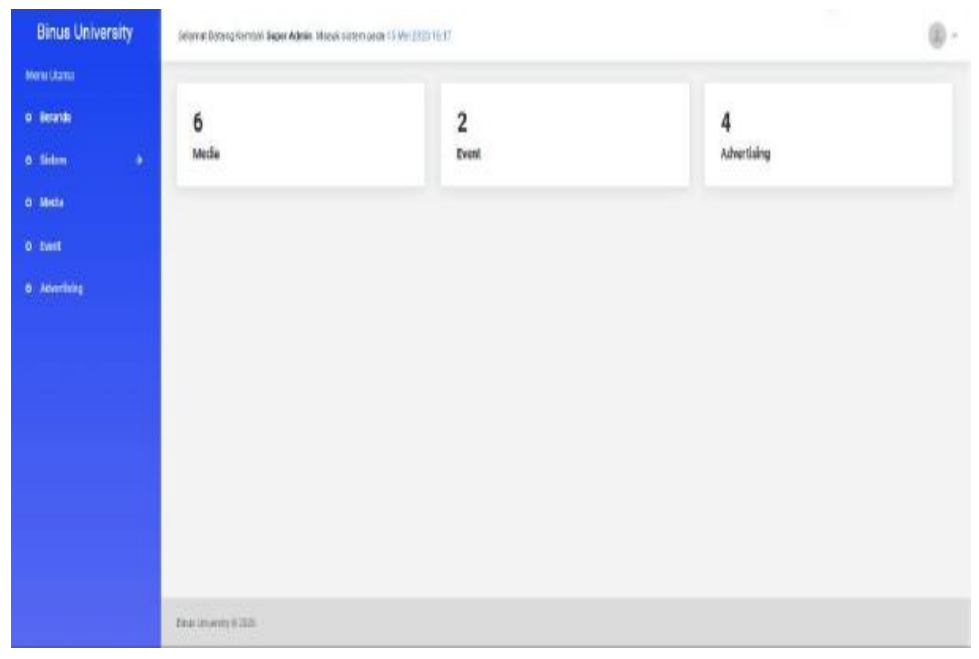

Figure 6: Display homepage after login

\subsection{Frontend System}

Figure 7 is a frontend picture of a website based smart mirror, which will appear through the Raspberry Pi which is placed behind the mirror.

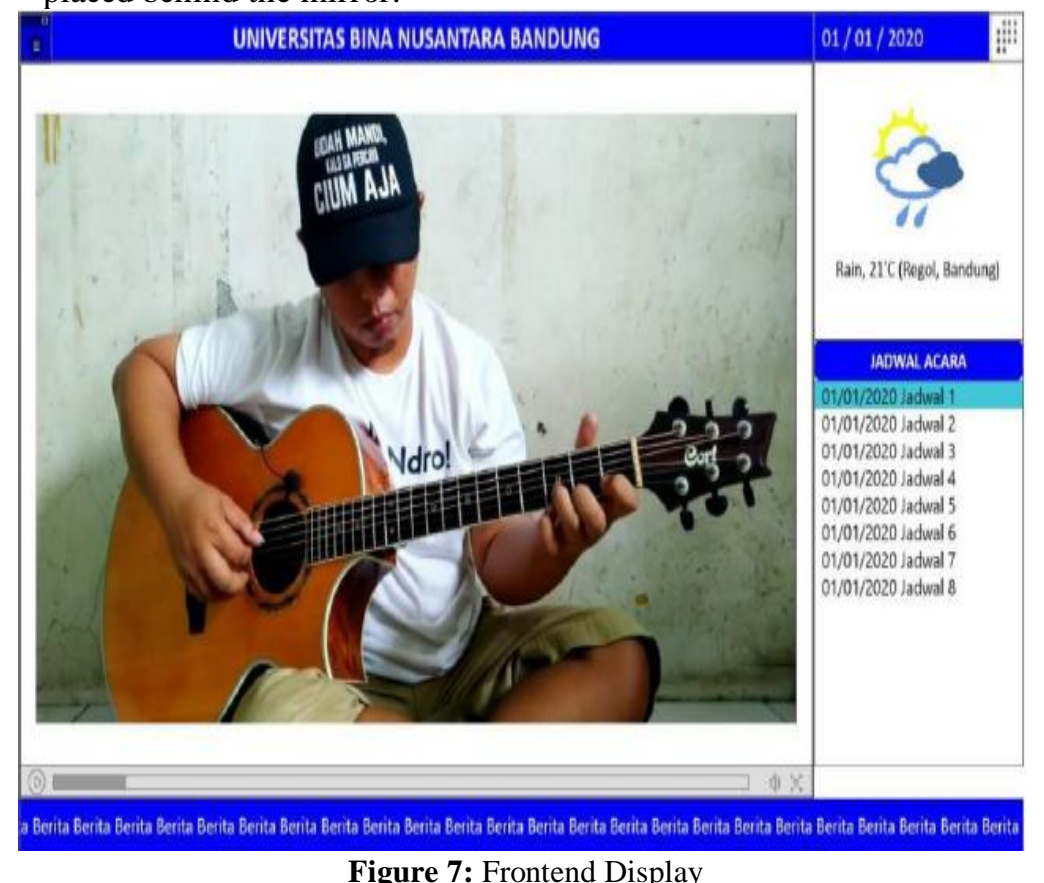

Figure 7: Frontend Display 


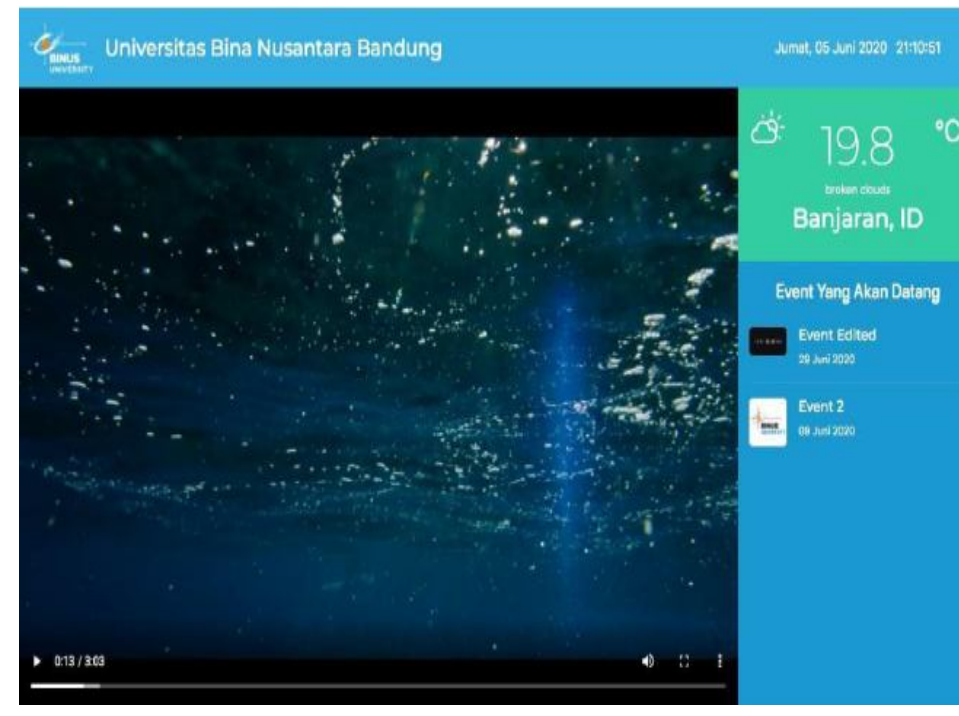

Figure 8: Frontend Building

Figure 8 is a frontend image of a website-based smart mirror. Which event also displays media for other information such as video and video slide presentations. Information that appears on this website-based frontend is arranged on the web admin. So later, each user can enter the information that will be displayed in accordance with what is needed.

\subsection{Configuration with Raspberry PI}

At this stage will explain how the default chromium web browser application raspbian which will automatically become startup / initial boot when Raspberry is first turned on / boot/startup.

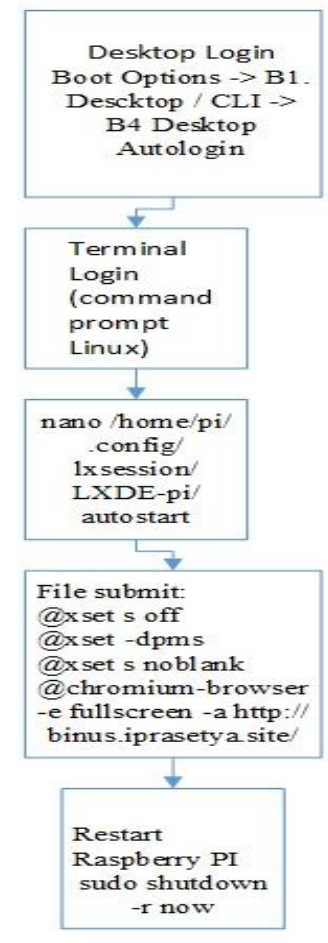

Figure 9: Configuration Raspberry Pi

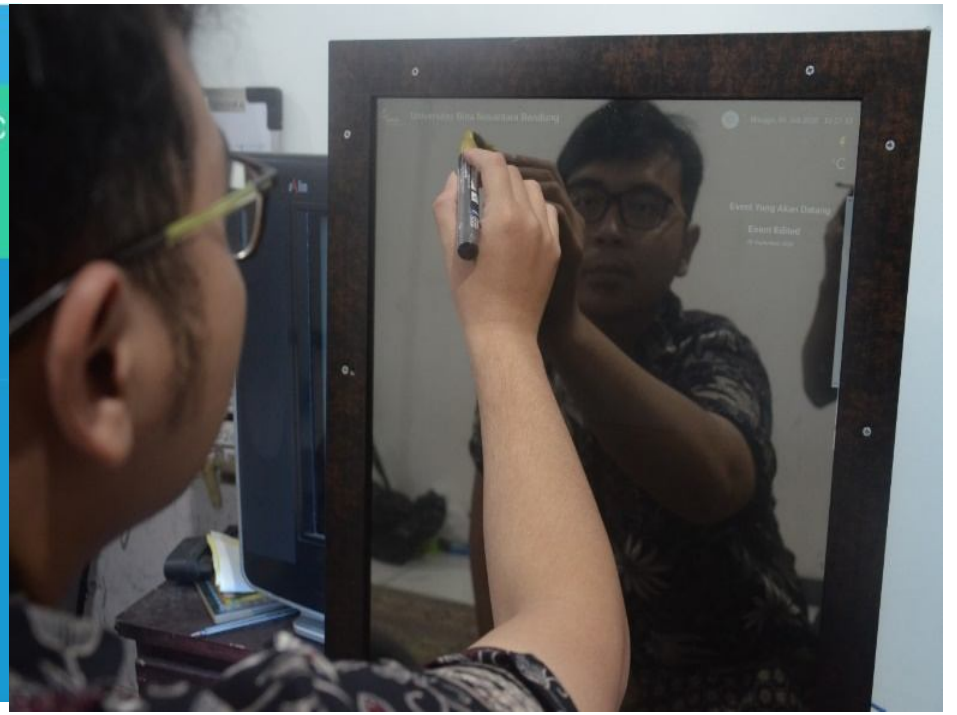

Figure 10: Result Smart Mirror

Figure 10 is a picture displaying information displayed on the configured Raspberry Pi. A visible mirror reflects the person in front of him and simultaneously displays information in the form of schedules, time, weather and video media player. The monitor used in this study is a 19" LG 19M38A LED monitor. In the construction of this smart mirror, the monitor is disassembled and removed from the outer casing. This is so that the monitor can stick to the glass to be made. Smart Mirror is the most important part of a smart mirror. In this study, the glass was made to adjust to the size of the LED monitor. The specifications of the glass used can be seen in the following table.

Table 2. Specification Smart Mirror

\begin{tabular}{|c|c|}
\hline Type & \\
\hline Size & Width $41 \mathrm{~cm} \mathrm{x} \mathrm{Length} 84 \mathrm{~cm}$ \\
\hline Thickness & $2 \mathrm{~mm}$ \\
\hline Layer & One Way Window Film 60\% \\
\hline
\end{tabular}

The smart mirror is expected to help as a reminder as well as to see the latest event information, current time, current weather to information in the form of video.

\subsection{System Testing}

The results of the research turned out to be successful in conducting several tests on software and hardware systems. done to ensure if a smart mirror system has met the requirements. There are several parts involved in the testing section, which is a special test. Data in the form of expected results are tangible results. The terms "Success" and "Fail" appear when field trials have been done with good or bad results. To be applied and published on the system to be developed. The simulation is done twice so that credibility can also be seen. Table 3 . shows the results of unit tests conducted by the researcher. 
Table 3: System Testing Result

\begin{tabular}{|l|l|l|l|}
\hline Test Case & $\begin{array}{l}\text { Expected } \\
\text { Result }\end{array}$ & $\begin{array}{l}\text { Actual } \\
\text { Result (1) }\end{array}$ & $\begin{array}{l}\text { Actual } \\
\text { Result (1) }\end{array}$ \\
\hline $\begin{array}{l}\text { Raspberry Pi } \\
\text { Configuration }\end{array}$ & $\begin{array}{l}\text { Can log in } \\
\text { Raspberry Pi }\end{array}$ & Success & Success \\
\hline Database Setup & $\begin{array}{l}\text { Display } \\
\text { Configuration } \\
\text { Database }\end{array}$ & Success & Success \\
\hline $\begin{array}{l}\text { Connect } \\
\text { Database to } \\
\text { Raspi }\end{array}$ & Can Connect & Fail & Success \\
\hline $\begin{array}{l}\text { Login Menu } \\
\text { Dashboard } \\
\text { Menu }\end{array}$ & $\begin{array}{l}\text { Can Display } \\
\text { Login Menu }\end{array}$ & Success & Success \\
\hline $\begin{array}{l}\text { Dashboard } \\
\text { Menu }\end{array}$ & Success & Success \\
\hline $\begin{array}{l}\text { Fisplaytend } \\
\text { Mirrored and } \\
\text { functioning } \\
\text { devices }\end{array}$ & $\begin{array}{l}\text { Display Menu } \\
\text { Frontend }\end{array}$ & Success & Success \\
\hline $\begin{array}{l}\text { Influence on } \\
\text { learning }\end{array}$ & $\begin{array}{l}\text { Increase } \\
\text { lecturer-studen } \\
\text { t innovation }\end{array}$ & Success & Success \\
\hline
\end{tabular}

\section{CONCLUSION}

Based on the results of research that affects the results of the implementation of smart mirrors at the University of Bandung has had a good influence on the institution, several tool concepts are based on the foundation of electrical science and database as information storage. Smart mirror has also been successfully tested with several tests with satisfactory results. The Smart mirror test successfully configures the raspberry pi login configuration and can be perceived in an application for enhanced learning. Smart mirror test on database settings has been successful and can be perceived in the application to improve learning. Smart mirror test has been successfully connected to the database so that it can be perceived in the application to improve learning. Smart mirror test has been successfully connected with Mirrored and functioning smart mirror devices so that it can be Perceived in its application to improve learning

\section{ACKNOWLEDGEMENT}

This work is supported by Research and Technology Transfer Office, Bina Nusantara University as a part of Penelitian Terapan Binus entitled $\ll$ Utilising Smart Mirror Technology on Internet of Things to Improve Interactive Learning > with contract number: No.025/VR.RTT/IV/2020 and contract date: 6 April 2020.

\section{REFERENCES}

[1] F. Z. Saudale, R. I. Lerrick, A. A. Parikesit, and F. Mariti, "Chemistry Teachers' Awareness, Understanding, and Confidence toward Computational Tools for Molecular Visualization," $J$. Pendidik. IPA Indones., vol. 8, no. 4, pp. 436-446, 2019.

[2] K. Uday Kumar Reddy, S. Shabbiha, and M. Rudra Kumar, "Design of high security smart health care monitoring system using iot," Int. J. Emerg. Trends Eng. Res., vol. 8, no. 6, pp. 2259-2265, 2020. https://doi.org/10.30534/ijeter/2020/09862020

[3] R. Ilham, S. Wisesa, W. Teguh, G. Wang, and Sfenrianto, "Smart contract formulation in general elections," Int. J. Emerg. Trends Eng. Res., vol. 8, no. 6, pp. 2233-2236, 2020. https://doi.org/10.30534/ijeter/2020/03862020

[4] F. M. Javed Mehedi Shamrat, M. Asaduzzaman, P. Ghosh, M. D. Sultan, and Z. Tasnim, "A web based application for agriculture: 'smart farming system,"' Int. J. Emerg. Trends Eng. Res., vol. 8, no. 6, pp. 2309-2320, 2020. https://doi.org/10.30534/ijeter/2020/18862020

[5] W. Xi and E. W. Patton, "Block-Based Approaches to Internet of Things in MIT App Inventor."

[6] D. A. Alboaneen et al., "Internet of Things Based Smart Mirrors: A Literature Review," ICCAIS 2020 3rd Int. Conf. Comput. Appl. Inf. Secur., no. 1, 2020.

[7] K. Chopra, K. Gupta, and A. Lambora, "Future Internet: The Internet of Things-A Literature Review," Proc. Int. Conf. Mach. Learn. Big Data, Cloud Parallel Comput. Trends, Prespectives Prospect. Com. 2019, pp. 135-139, 2019.

[8] Yusrizal, "Survey of the Use of Information and Communicaton Technology in the Border Regio," $J$. Teknol. Inf. dan Komun. Inf. dan Komun., vol. 5, no. 1, pp. 13-28, 2016.

[9] D. Evans, "IoT by Cisco 2011.pdf," Cisco Internet Bus. Solut. Gr., no. April, 2011.

[10] M. Murphy, "Population definitions for comparative surveys in education," Aust. Counc. Educ. Res., no. January, p. 33, 2016.

[11] A. Nimota, J. Kadir, T. A. Adebayo, and S. Abayomi, "Visionary Leadership and Staff Innovative Behaviour in Public Colleges of Education In Kwara State, Nigeria," Int. J. Educ., vol. 12, no. 2, p. 72, 2020.

[12]A. Yenas, "The importance of strengthening relationality: Experiences of women living with visible, physical disabilities in rural Papua New Guinea," Int. Educ. J., vol. 18, no. 2, pp. 95-109, 2019.

[13] D. Samsudin and T. I. Hardini, "the Influence of Learning Styles and Metacognitive Skills on Students' Critical Thinking in the Context of Student Creativity Program," Int. J. Educ., vol. 11, no. 2, p. 117, 2019. https://doi.org/10.17509/ije.v11i2.14750

[14] A. Johri, S. Jafri, R. N. Wahi, and D. Pandey, "Smart 
mirror: A time-saving and affordable assistant," 2018 4th Int. Conf. Comput. Commun. Autom. ICCCA 2018, pp. 1-4, 2018.

[15]R. Nadaf and V. Bonal, "Smart Mirror using Raspberry Pi as a Security and Vigilance System," 2019 3rd Int. Conf. Trends Electron. Informatics, no. Icoei, pp. 360-365, 2019.

[16] A. C. Njaka, N. Li, and L. Li, "Voice Controlled Smart Mirror with Multifactor Authentication," 2018 IEEE Int. Smart Cities Conf. ISC2 2018, 2019.

[17] V. Singh and D. Singh, "Smart Interactive Mirror Display," Proc. Int. Conf. Mach. Learn. Big Data, Cloud Parallel Comput. Trends, Prespectives Prospect. Com. 2019, pp. 140-145, 2019.

[18] M. Hamza, S. A. Lohar, S. Ghulamani, and A. Shah, "Smart Mirror for Home and Work Environment," pp. 1-4, 2020.

[19] M. Tani and N. Umezu, "Development of A Smart Mirror with Life Log Functions and Its Evaluation," 2018 IEEE 7th Glob. Conf. Consum. Electron. GCCE 2018, no. Gcce, pp. 851-852, 2018.

[20]C. Lee and A. Fumagalli, "Internet of Things Security-Multilayered Method for End to End Data Communications over Cellular Networks," IEEE 5th World Forum Internet Things, WF-IoT 2019 - Conf. Proc., pp. 24-28, 2019.

[21] S. Ziegler, S. Nikoletsea, S. Krco, J. Rolim, and J. Fernandes, "Internet of Things and crowd sourcing A paradigm change for the research on the Internet of Things," IEEE World Forum Internet Things, WF-IoT 2015 - Proc., pp. 395-399, 2015.

[22]G. Moller and D. Strawn, "Patent Application Publication ( 10 ) Pub . No .: US 2015 / 0144564 A1," vol. 1, no. 19, 2015. 